Invited review

\title{
Molecular basis of inherited calcium channelopathies: role of mutations in pore-forming subunits ${ }^{1}$
}

\author{
Lynn MCKEOWN, Philip ROBINSON, Owen T JONES ${ }^{2}$ \\ Faculty of Life Sciences, the University of Manchester, Manchester, UK
}

\author{
Key words \\ calcium channels; channelopathies; mutation \\ ${ }^{1}$ Project supported by funds from the \\ Biotechnology and Biological Sciences \\ Research Council UK (No 34/C15752).
}

\footnotetext{
${ }^{2}$ Correspondence to Dr Owen T JONES. Phn 44-0-161-275-5604.

Fax 44-0-161-275-5600.

E-mail owen.t.jones@manchester.ac.uk
}

Received 2006-05-19

Accepted 2006-05-30

doi: $10.1111 / \mathrm{j} .1745-7254.2006 .00394 . \mathrm{x}$

\begin{abstract}
The pore-forming alpha subunits of voltage-gated calcium channels contain the essential biophysical machinery that underlies calcium influx in response to cell depolarization. In combination with requisite auxiliary subunits, these pore subunits form calcium channel complexes that are pivotal to the physiology and pharmacology of diverse cells ranging from sperm to neurons. Not surprisingly, mutations in the pore subunits generate diverse pathologies, termed channelopathies, that range from failures in excitation-contraction coupling to night blindness. Over the last decade, major insights into the mechanisms of pathogenesis have been derived from animals showing spontaneous or induced mutations. In parallel, there has been considerable growth in our understanding of the workings of voltage-gated ion channels from a structure-function, regulation and cell biology perspective. Here we document our current understanding of the mutations underlying channelopathies involving the voltage-gated calcium channel alpha subunits in humans and other species.
\end{abstract}

\section{Introduction}

Voltage-gated calcium channels (VGCCs) are critical determinants of physiological function in both excitable and non-excitable cells ${ }^{[1,2]}$. The ability of VGCCs to couple changes in membrane potential to the influx of the pivotal "second messenger" calcium $\left(\mathrm{Ca}^{2+}\right)$ bestow VGCCs with a unique and privileged position among ion channels in the coupling of electrical signaling to intracellular biochemical events. In tissues such as muscle and heart, VGCCs are used for specific functions such as neurotransmitter release and excitation-contraction coupling, respectively. More generally, VGCCs orchestrate cell excitability ${ }^{[3]}$, second messenger signaling ${ }^{[4]}$ and gene expression ${ }^{[5]}$.

Owing to such diverse roles, it is perhaps not too surprising that disruption in VGCC function has been implicated and, in many cases, demonstrated to underlie diverse inherited pathologies ranging from cardiac failure to epilepsy. The goal of this article is to review disparate data on such calcium "channelopathies" from a molecular perspective, focusing on the key pore-forming alpha subunits.

\section{Structure and function of VGCCs}

Although the existence of VGCCs had been known for many decades, their emergence as functionally discrete subtypes was not revealed until the pioneering electrophysiological studies of Tsien ${ }^{[6]}$, Lux ${ }^{[7]}$ and many others during the 1980s. Originally, VGCCs were classified into two groups, according to their functional and pharmacological characteristics: T VGCCs [low voltage-activated (LVA) subtype]; and $\mathrm{N}, \mathrm{L}, \mathrm{P} / \mathrm{Q}$, and R VGCCs [high voltage-activated (HVA) subtypes $]^{[8]}$ (Table 1). However, molecular cloning, expression and biochemical studies revealed inadequacies in the above classification notation and a more rigorous structurebased nomenclature (Table 1) was subsequently introduced ${ }^{[9]}$.

All VGCCs are large $(>400 \mathrm{kDa})$ heteromers comprised minimally of 3 core subunits $\alpha_{1}, \alpha_{2} / \delta$, and $\beta$ found in a $1: 1: 1$ stoichiometry $^{[8]}$. Expression studies in Xenopus oocytes ${ }^{[10,11]}$ and transfected mammalian cells ${ }^{[12-14]}$ have revealed that the $\alpha_{1}$ subunits contain the gating, channel pore and inactivation machinery required for function. However, interactions between $\alpha_{1}$ and the auxiliary $\alpha_{2} / \delta$ and $\beta$ subunits are required for optimal cell surface expression and channel kinetics. 
Table 1. Classification and nomenclature of VGCCs. Each channel type is defined by a specific core $\alpha 1$ protein subunit and current yielded, either high voltage-activated (HVA) or low voltage-activated (LVA). Adapted from Catterall et al ${ }^{[8]}$ and Ertel EA et al ${ }^{[9]}$.

\begin{tabular}{|c|c|c|c|c|c|}
\hline Name & Class & Current type & Alpha subunit & Protein size $(\mathrm{kDa})$ & Ligands \\
\hline CaV1.1 & $\mathrm{L}$ & HVA & $\alpha 1_{\mathrm{S}}$ & 212 & Dihydropyridines \\
\hline $\mathrm{CaV} 1.2$ & $\mathrm{~L}$ & HVA & $\alpha 1_{\mathrm{C}}$ & 240 & Dihydropyridines \\
\hline $\mathrm{CaV} 1.3$ & $\mathrm{~L}$ & HVA & $\alpha 1_{D}$ & 187 & Dihydropyridines \\
\hline CaV1.4 & $\mathrm{L}$ & HVA & $\alpha 1_{\mathrm{F}}$ & 222 & Dihydropyridines \\
\hline CaV2.1 & $\mathrm{P} / \mathrm{Q}$ & HVA & $\alpha 1_{\mathrm{A}}$ & 257 & $\omega$-Agatoxin IVA \\
\hline $\mathrm{CaV} 2.2$ & $\mathrm{~N}$ & HVA & $\alpha 1_{\mathrm{B}}$ & 262 & $\omega$-Conotoxin-GVIA \\
\hline $\mathrm{CaV} 2.3$ & $\mathrm{R}$ & HVA & $\alpha 1_{\mathrm{E}}$ & 252 & SNX-482 \\
\hline $\mathrm{CaV} 3.1$ & $\mathrm{~T}$ & LVA & $\alpha 1_{\mathrm{G}}$ & 250 & Kurtoxin ${ }^{a}$ \\
\hline $\mathrm{CaV} 3.2$ & $\mathrm{~T}$ & LVA & $\alpha 1_{\mathrm{H}}$ & 261 & Kurtoxin ${ }^{a}$ \\
\hline $\mathrm{CaV} 3.3$ & $\mathrm{~T}$ & LVA & $\alpha 1_{\mathrm{I}}$ & 224 & None \\
\hline
\end{tabular}

${ }^{a}$ Ligand is low affinity and most probably unreliable.

Additional protein interactions have been identified that appear necessary for trafficking and regulation (Table 2).

A cardinal feature of VGCCs is their extraordinary propensity for diversity. In mammals, $10 \alpha_{1}, 3 \alpha_{2} / \delta$ and $4 \beta$ subunit genes have been identified. Moreover, most of the RNA transcripts have been shown to undergo alternative splicing, and the number of reported variants is growing rapidly ${ }^{[8]}$. The precise nature of the $\alpha_{1}, \alpha_{2} / \delta$ and $\beta$ gene products in the VGCC complexes define their biophysical characteristics, therefore such diversity has significant functional implications ${ }^{[8]}$. However, the contribution of any ion channels to integrative physiology also depends on their distribution. Thus, it is notable that specific VGCCs have unique, but often overlapping, patterns of expression in discrete regions of brain and other tissues. Even the distribution over the cell surface can differ ${ }^{[15-22]}$, suggesting that diversity is used to hone voltage-dependent $\mathrm{Ca}^{2+}$ influx to the demands of discrete functional compartments ${ }^{[23]}$.

An emerging paradox concerns a subunit, termed $\gamma$, first identified as a constituent of the skeletal muscle VGCC but now known to have relatives in heart and brain ${ }^{[24]}$. Precisely what function these $\gamma$ subunits serve is unresolved. Expression studies suggest an ability to normalize calcium currents to those resembling endogenous VGCCs ${ }^{[25]}$. However, not all $\gamma$ subunits show this effect and one subunit, $\gamma_{2}$, has been shown to interact with the AMPA-subtype of glutamate receptors $^{[26]}$.

\section{$\mathrm{Ca}^{2+}$ channelopathies}

Inherited defects in VGCCs give rise to some of the most interesting and widely studied channelopathies ${ }^{[27]}$. Here we summarize, specifically, current information on those defects arising from mutations in the pore-forming alpha subunits in human and other model systems (Table 1).

CaV1.1 $\left(\alpha 1_{s}\right)$ The pore-forming subunit of CaV1.1, encoded in humans by the CACNA1S (formerly CACNL1A3) gene on chromosome $1 \mathrm{q} 31-32^{[28]}$, is expressed mainly in skeletal muscle traverse tubules where it mediates excitation-contraction coupling and calcium homeostatsis ${ }^{[29,30]}$.

Muscular dysgenesis in mice is a lethal mutation derived from a frameshift at nucleotide 4010. The resulting deletion of the C-terminus leads to a loss in muscle contraction and was the first mutation reported to affect calcium currents in vivo $^{[31,32]}$. Missense mutations in CACNA1S have been identified in human cases of hypokalemic periodic paralysis (hypoPP) and malignant hyperthermia susceptibility (MHS) ${ }^{[33-38]}$. The Arg-His or glycine substitutions found in hypoPP (Table 1) are located in the voltage-sensing segments (S4) of domains II and IV, leading to a loss of myotube function $^{[33,39,40]}$. Arg-His mutations have also been found in patients suffering from MHS. However, although both allelic, MHS and hypoPP appear to be distinct non-overlapping diseases $^{[41]}$. Genetic studies of MHS have mainly linked associated mutations to the ryanodine receptor (RyR). However, as the RyR comes under the control of CaV1.1 and the R1086H mutation is located in the cytoplasmic loop between transmembrane spanning segments 3 and 4 , such mutations might disrupt the functional link between the CaV1.1 and RyR ${ }^{[36]}$.

CaV1.2 $\left(\alpha \mathbf{1}_{\mathbf{C}}\right) \mathrm{CaV1.2}$ is primarily localized to cardiac or smooth muscle but is also found in endocrine cells and neurones. Functionally, CaV1.2 mediates excitation-contraction coupling in smooth and cardiac muscle, hormone secretion and action potential propagation in sino-atrial and atrio- 
Table 2. Summary of major cytoplasmic proteins interacting with VGCC $\alpha 1$ subunits, their binding sites and roles.

\begin{tabular}{|c|c|c|c|}
\hline Protein & VGCC 1 binding site & Role/effect & Reference \\
\hline Syntaxin 1 & Synprint motif (II-III linker) & SNARE member, vesicle exocytosis & 149 \\
\hline SNAP-25 & Synprint motif (II-III linker) & SNARE member, vesicle exocytosis & 150 \\
\hline Cysteine string protein & Synprint motif (II-III linker) & Vesicle exocytosis & 151 \\
\hline Synaptotagmin & Synprint motif (II-III linker) & Vesicle exocytosis & 152 \\
\hline CASK & C-terminus & VGCC-vesicle coupling & 153 \\
\hline MINT-1 & C-terminus & VGCC-vesicle coupling & 153 \\
\hline Calmodulin & C-terminus (IQ domain) & Post $\mathrm{Ca}^{2+}$-influx inactivation & 154 \\
\hline G-protein $\beta \gamma$ subunit & Domain I-II linker, C-terminus & GPCR-coupled inactivation & 155 \\
\hline $\begin{array}{l}\text { Protein kinase } \mathrm{C} \text {, } \\
\text { protein kinase } \mathrm{A}\end{array}$ & $\begin{array}{l}\text { Domain I-II linker, Synprint motif, } \\
\text { C- and N-termini }\end{array}$ & Dependent on channel type and binding site & 1 \\
\hline AKAP-79 & Domain II-III linker & Postsynaptic L-type channel trafficking & 156 \\
\hline Calbindin & C-terminus & $\begin{array}{l}\text { Decrease L-type channel activity in pancreatic } \\
\text { beta cells }\end{array}$ & 157 \\
\hline $\begin{array}{l}\text { CaMKII }\left(\mathrm{Ca}^{2+} / \text { calmodulin- }\right. \\
\text { dependent kinase II })\end{array}$ & C-terminus & Facilitation of $\mathrm{Ca}^{2+}$ current & 158 \\
\hline
\end{tabular}

ventricular nodes ${ }^{[42]}$.

The CaV1.2 subunit is encoded by the CACNA1C (formerly $C A C N L 1 A 1$ ) gene on chromosome $12 \mathrm{p} 13.3^{[43]}$. In mice, knockout of the CaV1.2 gene is lethal due to cardiac dysfunction (Seisenberger et al 2000). However, two de novo missense mutations in CaV1.2 in humans result in Timothy syndrome, a multi-system disorder including syndactyly, immune deficiency, long QT syndrome and ventricular arrhythmias during infancy ${ }^{[4]}$. These gain of function phenotypes arise from highly conserved glycine substitutions for either Arg at 406 or Ser at 402 ${ }^{[44]}$. Mutation G406 is located in alternatively spliced exon $8 \mathrm{~A}$, at the cytoplasmic face of the transmembrane segment S6 of domain I, whereas mutation G402 is located within the transmembrane region. As glycine can act as a hinge-point in $\alpha$ helices, such mutations have been suggested to disrupt the activation gate ${ }^{[44]}$. Further support for the role of CaV1.2 in cardiac development and dysfunction comes from studies on zebrafish whose embryos can survive without blood flow for several days. In their study, Rottbauer et $a l^{[45]}$ mapped the genetic mutations responsible for the zebrafish isl lethal mutant. Mutants expressing two isl nonsense mutations at M379 or M458 (which both caused premature truncation of $\mathrm{CaV} 1.2$ ) present with abnormal heart growth during development.

CaV1.3 $\left(\alpha \mathbf{1}_{\mathbf{D}}\right)$ The pore-forming subunit of the CaV1.1 channel is mainly expressed in endocrine cells of the pituitary and adrenal chromaffin cells, but is also found in sensory cells and in low densities in atrial muscle, heart and neurons. Originally classed as the neuroendocrine L-type channel, CaV1.3 plays a role in hormone secretion, mood behaviour, and control of cardiac rhythm at rest ${ }^{[46]}$.

The CaV1.3 subunit is encoded by the CACNA1D (formerly $C A C N L 1 A 2$ ) gene on chromosome $3 \mathrm{p} 14.3^{[47]}$. Insights into the role of Cav1.3 in cardiac tissue have largely evolved due to electrophysiology studies on cells from knockout mice ${ }^{[48]}$ and cardiac cells from human patients ${ }^{[49]}$. Although no human gene defect has been reported, animal models have provided useful insights into potential deficits. In one study, Wappl et al created a mouse model in which the high dihydropyridine sensitivity of $\mathrm{CaV} 1.2$ subunits was eliminated byreplacement of Thr1066 in helix IIIS5 with a tyrosine residue ${ }^{[50]}$. As the distribution of CaV1.2 and 1.3 often overlap, and they both mediate L-type currents, the creation of this mouse model allowed Sinnegger-Brauns et $a l$, to isolate the function of CaV1.3 in brain, pancreatic beta cells and the cardiovascular system ${ }^{[51]}$. These studies ruled out a direct role for $\mathrm{CaV} 1.3$ in insulin secretion, cardiac inotropy, and arterial smooth muscle contractility but suggested it might play a role in depression. Although no linkage of CaV1.3 channel mutations has been reported for human inherited diseases, mice carrying a targeted null allele display profound congenital deafness, thus providing insight into the molecular basis of CaV1.3 function in auditory processing ${ }^{[52,53]}$. Interestingly, the $i s e$, mutant form of zebrafish larvae displays a deafness-imbalance phenotype, arising through two mutations (R1250X and R284C) in a gene encoding for the CaV1.3 channel ${ }^{[54]}$. The first mutation involves exchange of an Arg codon for a stop codon at position 1250 and results in a nonsense mutation in domain IVS4 that disrupts the transmembrane region and removes the 
Table 3. The position of inherited and de novo mutations in $\alpha 1$ genes and their resulting phenotypes. Mutation refers to amino acid unless followed by (n) for nucleotide. Ic, intracellular loops; Ec, extracellular loops.

\begin{tabular}{|c|c|c|c|c|c|c|}
\hline Channel & Gene & Mutation & Type & Location & Inherited disease & Reference \\
\hline \multirow[t]{5}{*}{ CaV1.1 } & $C A C N A 1 S$ & $\mathrm{R} 528 \mathrm{H}$ & Missense & IIS4 & НуроРР & $33-35$ \\
\hline & & R528G & Missense & IIS4 & НуроРР & 38 \\
\hline & & $\mathrm{R} 1239 \mathrm{G}$ & Missense & IVS4 & НуроРР & 42 \\
\hline & & $\mathrm{R} 1239 \mathrm{H}$ & Missense & IVS4 & НуроРР & 133 \\
\hline & & $\mathrm{R} 1086 \mathrm{H}$ & Missense & Linker III-IV & MHS & 36,37 \\
\hline \multirow[t]{2}{*}{$\mathrm{CaV} 1.2$} & CACNAIC & G406R & Missense & IS6 & Timothy syndrome & 44,50 \\
\hline & & G402S & Missense & & Timothy syndrome & 44,50 \\
\hline \multirow[t]{24}{*}{$\mathrm{CaV} 1.4$} & $C A C N A 1 D$ & S229P & Missense & Ic loop IS4-S5 & XLCSNB & 133 \\
\hline & & 341 delC & Frameshift & Linker I II & XLCSNB & 55 \\
\hline & & G369D & Missense & IS6 & XLCSNB & 56,133 \\
\hline & & R508Q & Missense & Linker I II & XLCSNB & 56,134 \\
\hline & & $\mathrm{I} 745 \mathrm{~T}$ & Missense & IIS6 & XLCSNB & 136 \\
\hline & & R680X & Nonsense & Pore IIS5-S6 & XLCSNB & 57 \\
\hline & & $\mathrm{R} 830 \mathrm{X}$ & Nonsense & Ec loop IIIS1-S2 & XLCSNB & 55 \\
\hline & & R958X & Nonsense & IIIS4 & XLCSNB & 56 \\
\hline & & 991 insC & Frameshift & Pore IIIS5-S6 & XLCSNB & 55 \\
\hline & & $\mathrm{R} 1049 \mathrm{~W}$ & Missense & Pore IIIS5-S6 & XLCSNB & 56 \\
\hline & & L1068P & Missense & Pore IIIS5-S6 & XLCSNB & 133 \\
\hline & & $1159 \mathrm{delC}$ & Frameshift & Ec loop IVS1-S2 & XLCSNB & 55 \\
\hline & & $\mathrm{R} 1234 \mathrm{X}$ & Nonsense & IVS4 & XLCSNB & 55 \\
\hline & & $\mathrm{S} 1254 \mathrm{I}$ & Missense & IVS4 & XLCSNB & 57 \\
\hline & & $\mathrm{R} 1285 \mathrm{~S}$ & Missense & IVS4 & XLCSNB & 57 \\
\hline & & Q1348X & Nonsense & Pore IVS5-S6 & XLCSNB & 56 \\
\hline & & $\mathrm{L} 1364 \mathrm{H}$ & Missense & Pore IVS5-S6 & XLCSNB & 56,134 \\
\hline & & W $1386 \mathrm{X}$ & Nonsense & $\mathrm{C}$ terminal & XLCSNB & 55 \\
\hline & & W1440X & Nonsense & $\mathrm{C}$ terminal & XLCSNB & 133 \\
\hline & & $1516 \mathrm{delC}$ & Frameshift & C-terminal & XLCSNB & 135 \\
\hline & & K1591X & Nonsense & C-terminal & XLCSNB & 56 \\
\hline & & $\mathrm{R} 1919 \mathrm{H}$ & Missense & C-terminal & XLCSNB & 57 \\
\hline & & 3133 insC (n) & Frameshift & Pore IIIS5-S6 & XLCSNB & 56 \\
\hline & & $3658-3669(n)$ & Deletion & IVS2 & XLCSNB & 56 \\
\hline \multirow[t]{15}{*}{$\mathrm{CaV} 2.1$} & CACNA1A & R192Q & Missense & IS4 & FHM & 85 \\
\hline & & $\mathrm{R} 195 \mathrm{~K}$ & Missense & IS4 & FHM & 95 \\
\hline & & $\mathrm{S} 218 \mathrm{~L}$ & Missense & Ic loop IS4-S5 & FHM & 137 \\
\hline & & R583Q & Missense & IIS4 & FHM & 138 \\
\hline & & $\mathrm{T} 666 \mathrm{M}$ & Missense & Pore IIS5-S6 & FHM & 85 \\
\hline & & V714A & Missense & IIS6 & FHM & 85 \\
\hline & & D715E & Missense & IIS6 & FHM & 94 \\
\hline & & $\mathrm{K} 1336 \mathrm{E}$ & Missense & Ec loop III S3-S4 & FHM & 94 \\
\hline & & Y1385C & Missense & IIIS5 & FHM & 139 \\
\hline & & V1457L & Missense & Pore IIIS5-S6 & FHM & 140 \\
\hline & & $\mathrm{R} 1668 \mathrm{~W}$ & Missense & IVS4 & FHM & 95 \\
\hline & & $\mathrm{L} 1682 \mathrm{P}$ & Missense & IVS4 & FHM & 141 \\
\hline & & $\mathrm{W} 1684 \mathrm{R}$ & Missense & IVS4 & FHM & 95 \\
\hline & & V1696I & Missense & IVS5 & FHM & 95 \\
\hline & & $\mathrm{H} 253 \mathrm{Y}$ & Missense & Pore IS5-S6 & EA-2 & 92 \\
\hline
\end{tabular}




\begin{tabular}{|c|c|c|c|c|c|c|}
\hline Channel & Gene & Mutation & Type & Location & Inherited disease & Reference \\
\hline & & SS & Missplice & IIS2 & EA-2 & 142 \\
\hline & & 2145 del $8(n)$ & Frameshift & IIS5 & EA-2 & 92 \\
\hline & & $2317 \operatorname{de} 18(n)$ & Frameshift & Pore IIS5-S6 & EA-2 & 142,92 \\
\hline & & FS1067X & Frameshift & Linker II-III & EA-2 & 143 \\
\hline & & FS1144X & Frameshift & Linker II-III & EA-2 & 144 \\
\hline & & FS1294X & Frameshift & IIIS1 & EA-2 & 85,142 \\
\hline & & R1279X & Nonsense & IIIS2 & EA-2 & 145 \\
\hline & & SS & Missplice & IIIS3 & EA-2 & 85 \\
\hline & & $4451 \operatorname{delC}(n)$ & Frameshift & IIIS5 & EA-2 & 92 \\
\hline & & SS & Missplice & Pore IIIS5-S6 & EA-2 & 142 \\
\hline & & Y 1444X & Nonsense & Pore IIIS5-S6 & EA-2 & 142 \\
\hline & & $\mathrm{R} 1547 \mathrm{X}$ & Nonsense & Linker III-IV & EA-2 & 142 \\
\hline & & $5056 \operatorname{del} 8(\mathrm{n})$ & Frameshift & IVS1-S2 & EA-2 & 142 \\
\hline & & $5123 \mathrm{del}$ & Frameshift & IVS2 & EA-2 & 143 \\
\hline & & $\mathrm{R} 1662 \mathrm{H}$ & Missense & IVS4 & EA-2 & 146 \\
\hline & & $\mathrm{H} 1736 \mathrm{~L}$ & Missense & IVS5-S6 & EA-2 & 147 \\
\hline & & $\mathrm{E} 1757 \mathrm{~K}$ & Missense & Pore IVS5-S6 & EA-2 & 148 \\
\hline & & SS & Missplice & IVS3 & EA-2 & 87 \\
\hline & & 7213 GAG (n) & Expansion & C-terminal & Spinocerebellar ataxia type 6 & 96 \\
\hline & & R1664Q & Missense & IVS4 & & 149 \\
\hline \multirow[t]{15}{*}{$\mathrm{CaV} 3.2$} & CACNA1B & F161L & Missense & IS2-IS3 & Childhood absence epilepsy & 126 \\
\hline & & $\mathrm{E} 282 \mathrm{~K}$ & Missense & Pore IS5-S6 & Childhood absence epilepsy & 126 \\
\hline & & $\mathrm{C} 456 \mathrm{~S}$ & Missense & Linker I-II & Childhood absence epilepsy & 126 \\
\hline & & G499S & Missense & Linker I-II & Childhood absence epilepsy & 126 \\
\hline & & P648L & Missense & Linker I-II & Childhood absence epilepsy & 126 \\
\hline & & R744Q & Missense & Linker I-II & Childhood absence epilepsy & 126 \\
\hline & & A748V & Missense & Linker I-II & Childhood absence epilepsy & 126 \\
\hline & & G773D & Missense & Linker I-II & Childhood absence epilepsy & 126 \\
\hline & & G784S & Missense & Linker I-II & Childhood absence epilepsy & 126 \\
\hline & & V831M & Missense & IIS2 & Childhood absence epilepsy & 126 \\
\hline & & G848S & Missense & IIS3 & Childhood absence epilepsy & 126 \\
\hline & & D1463N & Missense & Pore IIIS5-S6 & Childhood absence epilepsy & 126 \\
\hline & & $\mathrm{A} 480 \mathrm{~T}$ & Missense & Linker I-II & IGE & 128 \\
\hline & & P618L & Missense & Linker I-II & IGE & 128 \\
\hline & & G775D & Missense & Linker I-II & IGE & 128 \\
\hline
\end{tabular}

carboxy-terminal tail. The second mutation substitutes a highly conserved Arg for a Cys residue at position 284 within the extracellular region of the pore loop between S5 and S6 of domain I.

CaV1.4 $\left(\alpha 1_{F}\right)$ The CaV1.4 subunit, encoded in humans by the gene $C A C N A 1 F$, maps to chromosome Xp11.4 ${ }^{[55]}$ and is mainly expressed in retinal rods and bipolar cells, spinal cord, adrenal gland and mast cells. As its main cellular function is thought to be neurotransmitter release from photoreceptors, it is no surprize that mutations in this channel are involved with inherited diseases of the eye.

The locus for X-linked congenital stationary night blindness type 2 (XLCSNB-2) was mapped to the CACNA1F gene ${ }^{[55,56]}$ and several mutations have since been identified.
In case studies of patients with XLCSNB, over $73 C A C N A 1 F$ mutations have been detected, of which $51 \%$ are nonsense mutations, $32 \%$ missense mutations and $8 \%$ frameshifts ${ }^{[57]}$. A list of several of the mutations identified and their positions within the channel is given in Table 2. Very recently, Wei and Hemmings detected a genetic association between schizophrenic patients and the CACNAIF locus, although the exact mutations are unknown ${ }^{[58]}$. The prevalence of visual abnormalities in schizophrenia makes an association with $C A C N A 1 F$ especially interesting.

CaV2.1 $\left(\alpha \mathbf{1}_{\mathrm{A}}\right)$ The P/Q-type calcium channel CaV2.1 (alpha1A) represents one of the most important channels both from a physiological perspective and its role in channelopathy. Found throughout the nervous system, 
CaV2.1 is considered to be the primary VGCC controlling fast neurotransmitter release, especially at excitatory synapses. Not surprisingly, CaV2.1 is found in high concentrations in the presynaptic nerve terminus, where it exists in discrete release sites that are more efficiently coupled to the vesicle release machinery than other VGCCs $^{[59-62]}$. However, CaV2.1 is also found throughout the dendritic arbour, especially in cerebellar Purkinje cells, where it contributes to integrative dendritic physiology ${ }^{[63]}$.

Historically, one of the first lines of evidence linking CaV2.1 to neurological disorders came from studies of the tottering (tg) mouse ${ }^{[64]}$. The $t g$ mouse is a neurological mutant displaying ataxia, and involuntary spasms indicative of tonicclonic seizures as well as neurophysiological signs of absence epilepsy ${ }^{[65]}$. The underlying defect in $t g$ mice has been identified, through positional cloning, as a point mutation $(\mathrm{P} 601 \mathrm{~L})$ in cacnala, the mouse CaV2.1 gene $^{[64]}$. Using whole cell patch clamp methods, Wakamori et al found significant (40\%) decreases in P-type $\left(\mathrm{Ba}^{2+}\right)$ currents in dissociated Purkinje cells obtained from $\mathrm{tg} / \mathrm{tg}$ versus wild-type ( $w t)$ mice that could be replicated in a simple heterologous expression system ${ }^{[66]}$. Surprisingly, they found no change in the voltage-dependence of activation or inactivation, single channel conductance or reversal potential, suggesting that the decreased current density is not due to impaired ion conductance or activation/inactivation mechanisms.

Three other mouse mutations showing varying degrees of seizure activity have been identified that map to the cacnala locus rocker $(r k r)$, tottering leaner $\left(\operatorname{tg}^{l a}\right)$ and rolling Nagoya $\left(\operatorname{tg}^{r o l}\right)^{[64,67,68]}$. Remarkably, each mutant mouse shows considerable differences in the extent and times of onset of seizure, cerebellar atrophy and ataxia. Thus $t g, \operatorname{tg}^{l a}$ and $r k r$ but not $t g^{r o l}$ mice show seizure activity, whereas $t g^{l a}, r k r$ and $\operatorname{tg}^{\text {rol }}$ but not $t g$ mice show marked ataxia ${ }^{[65,67-69]}$.

Rocker arises through a point mutation within the extracellular $\mathrm{S}_{5}-\mathrm{S}_{6}$ region (T1310K) of domain $\mathrm{III}^{[67]}$. Surprisingly, the precise effect of the $r k r$ mutation on $\mathrm{P} / \mathrm{Q}$ currents has not been forthcoming, but is likely to resemble those in $t g$ mice. Adistinct mutation in domain III, (R1262G), within the $\mathrm{S}_{4}$ voltage sensor, occurs in $\operatorname{tg}^{r o l}$ mice ${ }^{[68]}$. This mutation displays a marked reduction in the voltage sensitivity of channel activation. The $\operatorname{tg}^{l a}$ mutant has absence seizures, severe ataxia and cerebellar damage ${ }^{[70]}$. In $\operatorname{tg}^{l a}$, a point mutation at a splice/donor consensus sequence leads to aberrant RNA splicing in the region encoding the carboxy terminus of the $\alpha_{1 \mathrm{~A}}$ subunit. As a result, translation yields two primary protein products corresponding to truncated $\mathrm{CaV} 2.1$ subunits bearing a novel and distinct $\mathrm{C}$-termini. Electrophysiological studies on Purkinje cells show that the major deficit caused by the $\operatorname{tg}^{l a}$ mutation is a $60 \%$ reduction in $\mathrm{P} / \mathrm{Q}$-type currents or current densities compared to the wild-type mouse ${ }^{[66,71,72]}$. Single channel recordings suggest the decrease in current densities is not due to effects on either the channel conductance or lifetimes ${ }^{[72]}$, but due to effects on channel opening probability $\left(\mathrm{P}_{\mathrm{o}}\right)$ or, more likely, a decrease in channel densities at the cell surface, perhaps due to a trafficking defect. Interestingly, in transfected cells, only the $\operatorname{tg}^{l a}$ short form shows a significant reduction in current density ${ }^{[66]}$.

Just how the phenotypes of these spontaneous mouse mutants arise is unclear but might give insight into the analogous human conditions ${ }^{[73]}$. In general, aberrant activity of CaV2.1 channels cannot be functionally compensated for at many central synapses. Apart from the 'gain of function' FHM mutations (below), impairment of neurotransmission appears to be the rule for CaV2.1 knockout ${ }^{[74-76]}, \operatorname{tg} / \mathrm{tg}^{(77)}$ and $\mathrm{tg} / \mathrm{tg}^{\mathrm{rol}[78,79]}$. However, at the climbing fiber-Purkinje cell synapse, evoked glutamate release is similar between wildtype and $\mathrm{CaV} 2.1^{-/-}, \operatorname{tg}^{\text {rol }} / \mathrm{tg}^{\text {rol }}$ or $\mathrm{tg} / \mathrm{tg}$ mice $^{[76,78]}$. Inhibitory transmission does not appear to be affected ${ }^{[80]}$. An obvious complication is the degree to which alternate VGCCs can stand in for the aberrant CaV2.1 channels and to what extent this might contribute to the neurological phenotype. Based on their similar trafficking and biophysical properties, the most likely replacements are expected to be the CaV2.2 VGCCs. Indeed, compensation by $\mathrm{CaV} 2.2$ has been documented at the calyx of Held synapse in $\mathrm{CaV}, \mathrm{CaV} 2.1^{-/-}$knockout mice and other mutants ${ }^{[74,77,78,81]}$. However, there is also evidence for upregulation of both $\mathrm{CaV} 2.2$ and $\mathrm{CaV} 2.3$ at the neuromuscular junction of CaV2.1 $1^{-/-}$mice ${ }^{[82]}$.

In humans, the gene encoding $\mathrm{CaV} 2.1$ is designated as $C A C N A 1 A$ (formerly known as CACNLA4) and is localized to a large $300 \mathrm{~kb}$ region containing 47 exons at chromosome position $19 \mathrm{p} 13^{[83]}$. Whereas gene expression yields a primary transcript of $9.8 \mathrm{~kb}$, several splice variants have been identified $^{[84]}$, most notably an isoform that differs in exon 37 by 97 nucleotides.

In humans, the cardinal mutation associated with CaV2.1 is a rare disorder termed episodic ataxia type 2 (EA-2) that causes paroxysmal attacks of cerebellar ataxia that can last for several days. In 1996, Ophoff et al identified 2 mutations in unrelated patients displaying EA-2 that mapped to the $C A C N A 1 A$ gene $^{[85]}$. One mutation involves a base deletion and the other occurs at a splice junction site, but both are predicted to lead to a frameshift such that the $\mathrm{CaV} 2.1$ protein is truncated prematurely after the $\mathrm{S} 1$ region of domain III (Figure 1). The partially complete channel is, thus, predicted to be non-functional or to be incorrectly folded and trafficked. More recently, additional familial EA-2 mutations have been 


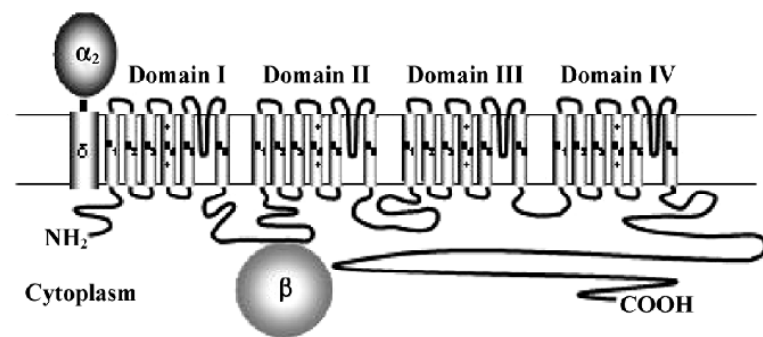

Figure 1. The predicted structure of a prototypical VGCC consists of an $\alpha 1$ pore-forming subunit and at least two auxiliary/regulatory subunits, $\beta$ and $\alpha 2 \mathrm{~d}$. The $\alpha 1$ subunit is a transmembrane protein organized into 4 repeating domains (I-IV), each containing 6 hydrophobic transmembrane regions (S1-S6). Segments S5 and S6 of each domain line the channel pore (P loop) and S4 is designated as the voltage sensor.

identified that induce mis-splicing either through a G-A substitution at an intron-exon boundary or, especially interesting, through a $4 \mathrm{bp}$ ACGT deletion within an intron (the first described for $C A C N A 1 A$ ), which might unmask a cryptic splice downstream ${ }^{[86]}$. Typically, clinical signs of EA-2 are evident prior to adulthood. However, just recently, a case of late-onset (aged 61 years) EA-2 has been identified involving a $9 \mathrm{bp}$ insertion in the cytoplasmic domain II-III linker. To date this is the largest insertion reported for the human gene ${ }^{[87]}$. Quite what the mutation does is unclear. Although it lies within the II-III linker, it is just downstream of the synprint region for SNAP-25/syntaxin binding. Expression studies indicate a significant (approximately 82\%) reduction in current and a $20 \mathrm{mV}$ depolarization shift in activation threshold with some change in activation and inactivation kinetics. Together, these data might be indicative of an effect on gating. Why the clinical symptoms appeared so late in this patient is unclear. An examination of compensatory expression of other VGCCs in this patient would certainly be interesting. A novel CACNA1A mutation, IVS36$2 \mathrm{~A}>\mathrm{G}$, at the 3 ' acceptor splice site of intron 36 was identified by sequencing ${ }^{[88]}$. It is the first described $C A C N A 1 A$ acceptor splice site mutation and the most C-terminal EA-2-causing mutation reported to date.

Another highly debilitating CACNA1A channelopathy is the rare autosomal dominant disorder familial hemiplegic migraine (FHM). Characterized by intense attacks of migraine with aura, often lasting for several days, FHM has often been misdiagnosed as epilepsy or stroke ${ }^{[89]}$. Cerebellar dysfunction has also been noted in some families. Following the initial work by Ophoff et $a l^{[85]}$, several missense mutations have been found within $C A C N A 1 A$ that lead to increased calcium influx through the expressed channels ${ }^{[90]}$.
However, the precise biophysical characteristics conferred by the mutations on the CaV2.1 channel are not identical. Thus, single channel recordings on expressed channels show changes in gating with mutants T666M, V714A, and I1819L, but not R192Q. Recovery from inactivation can be slower (T666M) or faster (V714A and I1819L) compared to wild-type CaV2.1 ${ }^{[91]}$. Subsequent studies have found an increased propensity for activation at weakly depolarizing potentials for three additional FHM-associated mutants ${ }^{[92]}$. Powerful insights into the neuropathology of FHM have come from a recent study by Van den Maagdenberg et $a l^{[93]}$ who generated a transgenic mouse model bearing the human $C A C N A 1 A$ mutation R192Q. Recordings from cerebellar granule cells showed increased CaV2.1 channel current densities, which activated at more negative voltages in R192Q mice than wildtype channels. Significantly, the R192Q mice showed enhanced neurotransmission and susceptibility to cortical spreading depression. Taken together the above suggests that FHM is a CACNA1A channelopathy that arises through a gain of function that enhances neurotransmitter release.

As FHM and EA-2 both involve CACNA1A, an interesting question concerns the extent to which they overlap. In this respect it is notable that approximately $20 \%$ of FHM cases show signs of mild cerebellar ataxia ${ }^{[94]}$. Although crosscorrelational prediction is not straightforward, $83 \%$ of patients with six missense mutations associated with migraine also showed ataxia and or nystagmus ${ }^{[05]}$.

A third clinical disorder associated with mutations in $\mathrm{CaV} 2.1$ has been identified. Termed Spinocerebellar ataxia type 6 (SCA6), this disorder appears in early middle age (3040 years) and is characterized by a mild progressive (over a subsequent 25 years) cerebellar atrophy causing dysarthria, nystagmus, ataxia, loss of gait and sometimes death ${ }^{[96]}$. Unlike EA-2 and FHM, SCA6 appears to arise through a shift in the reading frame and triplet (CAG) repeat expansion at the distal carboxy terminus ${ }^{[97]}$. Based on a study by Ishikawa et $a l^{[98]}$ the critical size of the CAG encoded polyglutamine stretch appears to be 19 repeats, with cases showing longer stretches having poorer neurological outcomes and earlier disease onset. Precisely what functional effects the SCA6 remains unclear. In a model of SCA6, elongation of the polyglutamine tract in SCA6 CaV2.1 caused a concomitant hyperpolarizing shift of voltage-dependent inactivation to more negative potentials, suggesting an overall reduction of calcium influx might contribute to SCA6 symptomology. However, just recently, compelling evidence has been presented that a portion of the CaV2.1 carboxy-terminus is cleaved in vivo and can enter the nucleus by virtue of nuclear localization signals ${ }^{[99]}$. Although the wild-type carboxy ter- 
minal fragment is weakly toxic, a fragment containing an expanded polyglutamine tract (Q33) corresponding to SCA6 is highly toxic to Purkinje neurons and other cells. Thus, SCA6 might share a similar mechanism of action with some other expansion disorders where pathogenesis requires entry of a polyglutamine-containing fragment into the nucleus.

Given the above, one would anticipate that mutations in the human CaV2.1 gene are associated with epilepsy ${ }^{[100]}$. Nevertheless, the evidence has been slow to emerge. One early study found no statistically significant evidence that genetic variants of the $C A C N A 1 A$ gene might play a causative role in common forms of idiopathic generalized epilepsy (IGE) ${ }^{[101]}$. Moreover, reports of an allelic association of a silent single nucleotide polymorphism (SNP8) with IGE $^{[102,103]}$ have been refuted ${ }^{[104]}$. Nevertheless, there is growing recognition that in some cases patients with EA-2 also show an epilepsy phenotype most usually of a primary generalized nature ${ }^{[105,106]}$.

The first human EA-2-epilepsy case was described in 2001 by Jouvenceau et al in an 11-year-old who showed frequent episodes of ataxia and poorly controlled absence seizures, and generalized tonic-clonic seizures ${ }^{[105]}$. The underlying mutation was found to lie in exon 36 (C5733T) giving rise to a premature truncation behind the domain IV S6, and, thus, completeloss of the C-terminus. In an expression system, the primary effect of this mutation is a massive loss of functional channels at the cell surface. However, it is interesting to note that the mutation appears to have a dominant-negative effect when co-expressed with wild-type CaV2.1 (as anticipated for the heterozygous state). It is our contention that it is only a matter of time before further epilepsy-associated $C A N A 1 A$ mutations are documented.

CaV2.2 $\left(\alpha \mathbf{1}_{\mathbf{B}}\right)$ Given its established role alongside CaV2. 1 in neurotransmitter release, it is remarkable that mutations in the CACNA1B gene (locus 9q34) have not been identified in the human population. Based on studies in CaV2. $2^{-1-}$ knockout mice one would anticipate problems in nociception ${ }^{[107]}$, decreases in sympathetic nervous system function ${ }^{[108]}$ and alterations in response to ethanol ${ }^{[109]}$ and anaesthetics ${ }^{[110]}$.

CaV2.3 $\left(\alpha \mathbf{1}_{\mathrm{E}}\right)$ The CaV2.3 channel (CACNA1E) (locus $1 \mathrm{q} 25-\mathrm{q} 31)^{[83]}$ is primarily localized to the somata and dendrites of central neurones. However, such channels are also found in the nerve terminals of central synapses ${ }^{[111,112]}$ where they might participate in transmitter release ${ }^{[113]}$. Although no human mutations have been identified in $\mathrm{CaV} 2.3$, observations in knockout mice by Jing et al predict that mutations impairing this VGCC are likely to affect glucose-stimulated insulin release from pancreatic beta cells by facilitating the global entry of calcium needed for granule replenishment ${ }^{[114]}$.
CaV3.1 $\left(\alpha \mathbf{1}_{\mathbf{G}}\right)$ The CaV3.1 subunit gene CACNA1G, located on chromosome $17 \mathrm{q} 22^{[115]}$ is thought to encode a Ttype (ie low threshold) VGCC. This channel is highly expressed in brain, especially on dendrites, and it is considered to be the primary T-channel in the thalamus ${ }^{[116]}$. However, CaV3.1 is also found in the ovary, placenta and heart ${ }^{[117]}$ To date no mutations have been identified in inherited human diseases. However, studies on knockout mice indicate reduced sleep patterns ${ }^{[118,119]}$, bradycardia and delayed atriventricular conduction ${ }^{[5,120]}$.

CaV3.2 $\left(\alpha \mathbf{1}_{\mathbf{H}}\right)$ In humans, the CaV3.2 gene $(C A C N A 1 H)$ has been mapped to chromosomal locus $16 \mathrm{p} 13 \cdot 3^{[6,121]}$. This subunit appears to be widely expressed in brain (especially the neocortex), kidney, smooth muscle, liver and heart. Targeted knockout studies in the rat nociceptive root ganglion suggest CaV3.2 plays a role in nociception ${ }^{[7,122]}$. Knockout mice show constitutively constricted coronary arterioles and focal myocardial fibrosis ${ }^{[123]}$, and CaV3.1 knockouts in human spermatazoa demonstrate that $\mathrm{CaV} 3.2$ is a key player in the T-type current accompanying the acrosome reaction ${ }^{[124]}$. Mutations in CACNAIH are now thought to underlie diverse epilepsies. Thus, in 2003, Chen et al found 12 missense mutations in 14 patients with childhood absence epilepsy ${ }^{[125]}$, and several of the 12 appeared to promote calcium influx during activation ${ }^{[126]}$. Even more recently, a study by Heron et $a l^{[127]}$ identified 3 missense mutations and a single nonsense mutation in $C A C N A 1 H$ in a subset of patients with IGE. On expression, these latter mutations yield statistically significant changes in the kinetics of activation and inactivation of the $\mathrm{CaV} 3.2$ channel. Interestingly, many of these mutations lie in the same domain I-II linker region. Even more significant is the possibility that mutations in this region might block the selective inhibition of this VGCC by Gprotein $\beta 2 \alpha 2$ subunits $^{[128]}$. Changes in T-type channels have long been implicated in epilepsy ${ }^{[100]}$.

CaV3.3 $\left(\alpha \mathbf{1}_{\mathrm{I}}\right)$ In humans, the CACNAII gene maps to chromosome position $22 \mathrm{q} 12.3^{[129]}$. In common with the other T-type VGCCs it is expressed highly in brain ${ }^{[130]}$ where it is thought to play a role in thalamic oscillation ${ }^{[131]}$. Little is known about possible CaV3.3 gene defects, either in the human population or inferred from knockout animals.

\section{Summary}

With just a few exceptions, pathological mutations have now been identified in every VGCC pore-forming alpha subunit in humans. In many cases the pathology can be predicted on the basis of the tissue patterns of gene expression. Studies on spontaneous mouse mutants provide important 
clues to the human condition and, in the case of knockout or knockin mutants, might predict disease phenotype and outcome. What is especially striking is the extent to which small differences in function can have major and very distinct effects on behavior. Such phenotypic pleiotropy does not simply reflect gain or loss of VGCC function, but more subtle effects on biophysical parameters such as pore conduction, gating and inactivation kinetics. In some cases, effects could be attributed to sites of interaction with proteins involved in channel regulation. However, a largely unexplored area is the extent to which VGCC mutations affect channel trafficking to and from the cell surface. Just recently, Papazian's group ${ }^{[132]}$ identified mutations in $\mathrm{tg} / \mathrm{tg}$ mice that appear to disrupt trafficking of $\mathrm{CaV} 2.1$ to the cell surface. Preliminary work in our laboratory suggests that similar effects might occur in other VGCC mutants. Whatever their origin, it is clear that the list of VGCC mutations identified in the human population will continue to expand. It is our contention that a detailed understanding of the structural and functional basis of such mutations is essential for treating the disorders they manifest.

\section{References}

1 Felix R. Molecular regulation of voltage-gated $\mathrm{Ca}^{2+}$ channels. J Recept Signal Transduct Res 2005; $25: 57-71$.

2 Lacinova L. Voltage-dependent calcium channels. Gen Physiol Biophys 2005; 24(Suppl 1): 1-78.

3 Autret L, Mechaly I, Scamps F, Valmier J, Lory P, Desmadryl G. The involvement of CaV3.2/alpha1H T-type calcium channels in excitability of mouse embryonic primary vestibular neurones. J Physiol 2005; 567(Pt 1): 67-78.

4 Rizzuto R, Pozzan T. Microdomains of intracellular $\mathrm{Ca}^{2+}$ : molecular determinants and functional consequences. Physiol Rev 2006; 86: 369-408.

5 Weick JP, Groth RD, Isaksen AL, Mermelstein PG. Interactions with $\mathrm{PDZ}$ proteins are required for L-type calcium channels to activate cAMP response element-binding protein-dependent gene expression. J Neurosci 2003; 23: 3446-56.

6 Fox AP, Nowycky MC, Tsien RW. Kinetic and pharmacological properties distinguishing three types of calcium currents in chick sensory neurones. J Physiol 1987; 394: 149-72.

7 Yaari Y, Hamon B, Lux HD. Development of two types of calcium channels in cultured mammalian hippocampal neurons. Science 1987; 235: 680-2.

8 Catterall WA, Perez-Reyes E, Snutch TP, Striessnig J. International Union of Pharmacology. XLVIII. Nomenclature and structure-function relationships of voltage-gated calcium channels. Pharmacol Rev 2005; 57: 411-25.

9 Ertel EA, Campbell KP, Harpold MM, Hofmann F, Mori Y, Perez-Reyes E, et al. Nomenclature of voltage-gated calcium channels. Neuron 2000; 25: 533-5.

10 Mori Y, Friedrich T, Kim MS, Mikami A, Nakai J, Ruth P, et al. Primary structure and functional expression from complemen- tary DNA of a brain calcium channel. Nature 1991; 350: 398 402.

11 Williams ME, Brust PF, Feldman DH, Patthi S, Simerson S, Maroufi A, et al. Structure and functional expression of an $\omega$ conotoxin-sensitive human N-type calcium channel. Science 1992; 257: 389-95.

12 Williams ME, Feldman DH, McCue AF, Brenner R, Velicelebi G, Ellis SB, et al. Structure and functional expression of $\alpha 1, \alpha 2$, and $\beta$ subunits of a novel human neuronal calcium channel subtype. Neuron 1992; 8: 71-84.

13 Fujita Y, Mynlieff M, Dirksen RT, Kim M, Niidome T, Nakai J, et al. Primary structure and functional expression of the $\omega$ conotoxin-sensitive N-type calcium channel from rabbit brain. Neuron 1993; 10: 585-98.

14 Stea A, Dubel SJ, Pragnell M, Leonard JP, Campbell KP, Snutch TP. A $\beta$-subunit normalizes the electrophysiological properties of a cloned N-type calcium channel. Neuropharmacology 1993; 32: 1103-16.

15 Jones OT, Kunze DL, Angelides KJ. Localization and mobility of omega-conotoxin-sensitive $\mathrm{Ca}^{2+}$ channels in hippocampal CA1 neurons. Science 1989; 244: 1189-93.

16 Westenbroek RE, Ahlijanian MK, Catterall WA. Clustering of L-type $\mathrm{Ca}^{2+}$ channels at the base of major dendrites in hippocampal pyramidal neurons. Nature 1990; 347: 281-4.

17 Westenbroek RE, Hell JW, Warner C, Dubel SJ, Snutch TP, Catterall WA. Biochemical properties and subcellular distribution of an N-type calcium channel alpha 1 subunit. Neuron 1992; 9: 1099-15.

18 Hell JW, Westenbroek RE, Warner C, Ahlijanian MK, Prystay $\mathrm{W}$, Gilbert MM, et al. Identification and differential subcellular localization of the neuronal class $\mathrm{C}$ and class D L-type calcium channel alpha 1 subunits. J Cell Biol 1993; 123: 949-62.

19 Haydon PG, Henderson E, Stanley EF. Localization of individual calcium channels at the release face of a presynaptic nerve terminal. Neuron 1994; 13: 1275-80.

20 Mills LR, Niesen CE, So AP, Carlen PL, Spigelman I, Jones OT. $\mathrm{N}$-type $\mathrm{Ca}^{2+}$ channels are located on somata, dendrites, and a subpopulation of dendritic spines on live hippocampal pyramidal neurons. J Neurosci 1994; 14: 6815-24.

21 Elliott EM, Malouf AT, Catterall WA. Role of calcium channel subtypes in calcium transients in hippocampal CA3 neurons. J Neurosci 1995; 15: 6433-44.

22 Westenbroek RE, Sakurai T, Elliott EM, Hell JW, Starr TVB, Snutch TP, et al. Immunochemical identification and subcellular distribution of the $\alpha_{1 \mathrm{~A}}$ subunits of brain calcium channels. J Neurosci 1995 ; 15: 6403-18.

23 Johnston D, Magee JC, Colbert CM, Christie BR. Active properties of neuronal dendrites. Annu Rev Neurosci 1996; 19: 16586.

24 Klugbauer N, Dai S, Specht V, Lacinova L, Marais E, Bohn G, et al. A family of gamma-like calcium channel subunits. FEBS Lett 2000; 470: 189-97.

25 Dascal N, Chilcott G, Lester HA. Recording of voltage and $\mathrm{Ca}^{2+}$ dependent currents in Xenopus oocytes using an intracellular perfusion method. J Neurosci Methods 1991; 39: 29-38.

26 Chen L, Chetkovich DM, Petralla RS, Sweeney NT, Kawasaki Y, Wenthold RJ, et al. Stargazin regulates synaptic targeting of AMPA receptors by two distinct mechanisms. Nature 2000; 
408: 936-43.

27 Pietrobon D. Calcium channels and channelopathies of the central nervous system. Mol Neurobiol 2002; 25: 31-50.

28 Gregg RG, Couch F, Hogan K, Powers PA. Assignment of the human gene for the alpha 1 subunit of the skeletal muscle DHPsensitive $\mathrm{Ca}^{2+}$ channel (CACNL1A3) to chromosome 1q31-q32. Genomics 1993;15: 107-12.

29 Garcia J, McKinley K, Appel SH, Stefani E. $\mathrm{Ca}^{2+}$ current and charge movement in adult single human skeletal muscle fibres. J Physiol 1992; 454: 183-96.

30 Flucher BE, Franzini-Armstrong C. Formation of junctions involved in excitation-contraction coupling in skeletal and cardiac muscle. Proc Natl Acad Sci USA 1996; 93: 8101-6.

31 Beam KG, Knudson CM, Powell JA. A lethal mutation in mice eliminates the slow calcium current in skeletal muscle cells. Nature 1986; 320:168-170.

32 Chaudhari N. A single nucleotide deletion in the skeletal musclespecific calcium channel transcript of muscular dysgenesis (mdg) mice. J Biol Chem 1992; 267: 25636-9.

33 Ptacek LJ, Tawil R, Griggs RC, Engel AG, Layzer RB, Kwiecinski $\mathrm{H}$, et al. Dihydropyridine receptor mutations cause hypokalemic periodic paralysis. Cell 1994; 77: 863-8.

34 Jurkat-Rott K, Lehmann-Horn F, Elbaz A, Heine R, Gregg RG, Hogan $\mathrm{K}$, et al. A calcium channel mutation causing hypokalemic periodic paralysis. Hum Mol Genet 1994; 3:1415-9.

35 Elbaz A, Vale-Santos J, Jurkat-Rott K, Lapie P, Ophoff RA, Bady B, et al. Hypokalemic periodic paralysis and the dihydropyridine receptor (CACNL1A3): genotype/phenotype correlations for two predominant mutations and evidence for the absence of a founder effect in 16 caucasian families. Am J Hum Genet 1995; 56: 374-80.

36 Monnier N, Procaccio V, Stieglitz P, Lunardi J. Malignanthyperthermia susceptibility is associated with a mutation of the alpha 1-subunit of the human dihydropyridine-sensitive L-type voltage-dependent calcium-channel receptor in skeletal muscle. Am J Hum Genet 1997; 60: 1316-25.

37 Stewart SL, Hogan K, Rosenberg H, Fletcher JE. Identification of the Arg1086His mutation in the alpha subunit of the voltagedependent calcium channel (CACNA1S) in a North American family with malignant hyperthermia. Clin Genet 2001; 59: $178-84$.

38 Wang Q, Liu M, Xu C, Tang Z, Liao Y, Du R, et al. Novel CACNA1S mutation causes autosomal dominant hypokalemic periodic paralysis in a Chinese family. J Mol Med 2005; 83: 203-8.

39 Sipos I, Jurkat-Rott K, Harasztosi C, Fontaine B, Kovacs L, Melzer W, et al. Skeletal muscle DHP receptor mutations alter calcium currents in human hypokalaemic periodic paralysis myotubes. J Physiol 1995; 483: 299-306.

40 Lehmann-Horn F, Sipos I, Jurkat-Rott K, Heine R, Brinkmeier $\mathrm{H}$, Fontaine B, et al. Altered calcium currents in human hypokalemic periodic paralysis myotubes expressing mutant Ltype calcium channels. Soc Gen Physiol Ser 1995; 50: 101-13.

41 Marchant CL, Ellis FR, Halsall PJ, Hopkins PM, Robinson RL. Mutation analysis of two patients with hypokalemic periodic paralysis and suspected malignant hyperthermia. Muscle Nerve 2004; 30: 114-7.

42 Beam KG, Knudson CM, Powell JA. A lethal mutation in mice eliminates the slow calcium current in skeletal muscle cells. Nature 1986; 320: -168-70.

43 Sun W, McPherson JD, Hoang DQ, Wasmuth JJ, Evans GA, Montal M. Mapping of a human brain voltage-gated calcium channel to human chromosome 12p13-pter. Genomics 1992; 14: 1092-4.

44 Splawski I, Timothy KW, Decher N, Kumar P, Sachse FB, Beggs $\mathrm{AH}$, et al. Severe arrhythmia disorder caused by cardiac L-type calcium channel mutations. Proc Natl Acad Sci USA 2005; 102 : 8089-96

45 Rottbauer W, Baker K, Wo ZG, Mohideen MA, Cantiello HF, Fishman MC. Growth and function of the embryonic heart depend upon the cardiac-specific L-type calcium channel alpha1 subunit. Dev Cell 2001; 1: 265-75.

46 Zhang Z, He Y, Tuteja D, Xu D, Timofeyev V, Zhang Q, et al. Functional roles of $\mathrm{CaV1.3(alpha1D)}$ calcium channels in atria: insights gained from gene-targeted null mutant mice. Circulation 2005; 112: 1936-44.

47 Seino S, Yamada Y, Espinosa R 3rd, Le Beau MM, Bell GI. Assignment of the gene encoding the alpha 1 subunit of the neuroendocrine/brain-type calcium channel (CACNL1A2) to human chromosome 3, band p14.3. Genomics 1992; 13: 1375-7.

48 Matthes J, Yildirim L, Wietzorrek G, Reimer D, Striessnig J, Herzig S. Disturbed atrio-ventricular conduction and normal contractile function in isolated hearts from Cav1.3-knockout mice. Naunyn Schmiedebergs Arch Pharmacol 2004; 369: 55462.

49 Mangoni ME, Couette B, Bourinet E, Platzer J, Reimer D, Striessnig J, et al. Functional role of L-type Cav1.3 $\mathrm{Ca}^{2+}$ channels in cardiac pacemaker activity. Proc Natl Acad Sci USA 2003; 100: 5543-8.

50 Wappl E, Mitterdorfer J, Glossmann H, Striessnig J. Mechanism of dihydropyridine interaction with critical binding residues of L-type $\mathrm{Ca}^{+}$channel alpha 1 subunits. J Biol Chem 2001; 20; 276: 12730-5.

51 Sinnegger-Brauns MJ, Hetzenauer A, Huber IG, Renstrom E, Wietzorrek G, Berjukov S, et al. Isoform-specific regulation of mood behavior and pancreatic beta cell and cardiovascular function by L-type $\mathrm{Ca}^{2+}$ channels. J Clin Invest 2004; 113: 1430-9.

52 Platzer J, Engel J, Schrott-Fischer A, Stephan K, Bova S, Chen $\mathrm{H}$, et al. Congenital deafness and sinoatrial node dysfunction in mice lacking class D L-type $\mathrm{Ca}^{2+}$ channels. Cell 2000; 102: 8997.

53 Dou H, Vazquez AE, Namkung Y, Chu H, Cardell EL, Nie L, et al. Null mutation of alpha1D $\mathrm{Ca}^{2+}$ channel gene results in deafness but no vestibular defect in mice. J Assoc Res Otolaryngol 2004; 5: 215-26.

54 Sidi S, Busch-Nentwich E, Friedrich R, Schoenberger U, Nicolson T. gemini encodes a zebrafish L-type calcium channel that localizes at sensory hair cell ribbon synapses. J Neurosci 2004; 24: 4213-23.

55 Bech-Hansen NT, Naylor MJ, Maybaum TA, Pearce WG, Koop $\mathrm{B}$, Fishman GA, et al. Loss-of-function mutations in a calciumchannel alpha1-subunit gene in Xp11.23 cause incomplete Xlinked congenital stationary night blindness. Nat Genet 1998; 19: 264-7.

56 Strom TM, Nyakatura G, pfelstedt-Sylla E, Hellebrand H, Lorenz $\mathrm{B}$, Weber $\mathrm{BH}$, et al. An L-type calcium-channel gene mutated in 
incomplete X-linked congenital stationary night blindness. Nat Genet 1998; 19: 260-3.

57 Zeitz C, Minotti R, Feil S, Matyas G, Cremers FP, Hoyng CB, et al. Novel mutations in CACNA1F and NYX in Dutch families with $\mathrm{X}$-linked congenital stationary night blindness. Mol Vis 2005; 11: 179-83.

58 Wei J, Hemmings GP. A further study of a possible locus for schizophrenia on the $\mathrm{X}$ chromosome. Biochem Biophys Res Commun 2006; 344: 1241-5.

59 Matsushita K, Wakamori M, Rhyu IJ, Arii T, Oda S, Mori Y, et al. Bidirectional alterations in cerebellar synaptic transmission of tottering and rolling $\mathrm{Ca}^{2+}$ channel mutant mice. J Neurosci $2002 ; 22: 4388-98$.

60 Qian J, Noebels JL. Presynaptic $\mathrm{Ca}(2+)$ influx at a mouse central synapse with $\mathrm{Ca}(2+)$ channel subunit mutations. J Neurosci 2000; 20:163-70

61 Mintz IM, Sabatini BL, Regehr WG. Calcium control of transmitter release at a cerebellar synapse. Neuron 1995; 15: 67588 .

62 Wu LG, Westenbroek RE, Borst JGG, Catterall WA, Sakmann B. Calcium channel types with distinct presynaptic localization couple differentially to transmitter release in single calyx-type synapses. J Neurosci 1999; 19: 726-36.

63 Llinas RR, Sugimori M, Cherksey B. Voltage-dependent calcium conductances in mammalian neurons. The P channel. Ann NY Acad Sci 1989; 560: 103-11.

64 Fletcher CF, Lutz CM, O'Sullivan TN, Shaughnessy JD Jr, Hawkes $\mathrm{R}$, Frankel WN, et al. Absence epilepsy in tottering mutant mice is associated with calcium channel defects. Cell 1996; 87: $607-17$.

65 Noebels JL, Sidman RL. Inherited epilepsy: spike-wave and focal motor seizures in the mutant mouse tottering. Science 1979; 204:1334-6.

66 Wakamori M, Yamazaki K, Matsunodaira H, Teramoto T, Tanaka I, Niidome T, et al. Single tottering mutations responsible for the neuropathic phenotype of the P-type calcium channel. J Biol Chem 1998; 273: 34857-67.

67 Zwingman TA, Neumann PE, Noebels JL, Herrup K. Rocker is a new variant of the voltage-dependent calcium channel gene Cacna1a. J Neurosci 2001;21:1169-78.

68 Mori Y, Wakamori M, Oda S, Fletcher CF, Sekiguchi N, Mori E, et al. Reduced voltage sensitivity of activation of $\mathrm{P} / \mathrm{Q}$-type $\mathrm{Ca}^{2+}$ channels is associated with the ataxic mouse mutation rolling Nagoya (tg(rol)). J Neurosci 2000; 20: 5654-62.

69 Noebels JL. The biology of epilepsy genes. Annu Rev Neurosci 2003; 26: 599-625.

70 Tsuji S, Meier H. Evidence for allelism of leaner and tottering in the mouse. Genet Res 1971; 17: 83-88.

71 Lorenzon NM, Lutz CM, Frankel WN, Beam KG. Altered calcium channel currents in Purkinje cells of the neurological mutant mouse leaner. J Neurosci 1998;18: 4482-9.

72 Dove LS, Abbott LC, Griffith WH. Whole-cell and single-channel analysis of P-type calcium currents in cerebellar Purkinje cells of leaner mutant mice. J Neurosci 1998; 18: 7687-99.

73 Hess EJ. Migraines in mice? Cell 1996; 87: 1149-51.

74 Jun K, Piedras-Renteria ES, Smith SM, Wheeler DB, Lee SB, Lee TG, et al. Ablation of P/Q-type $\mathrm{Ca}^{2+}$ channel currents, altered synaptic transmission, and progressive ataxia in mice lacking the a1A -subunit. Proc Natl Acad Sci USA 1999; 96 : $15245-50$

75 Inchauspe CG, Martini FJ, Forsythe ID, Uchitel OD. Functional compensation of $\mathrm{P} / \mathrm{Q}$ by N-type channels blocks short-term plasticity at the calyx of held presynaptic terminal. J Neurosci 2004; 24: 10379-83

76 Miyazaki T, Hashimoto K, Shin HS, Kano M, Watanabe M. P/ Q-type $\mathrm{Ca}^{2+}$ channel alpha1A regulates synaptic competition on developing cerebellar Purkinje cells. J Neurosci 2004; 24: 173443 .

77 Qian J, Noebels JL. Presynaptic $\mathrm{Ca}^{2+}$ influx at a mouse central synapse with $\mathrm{Ca}^{2+}$ channel subunit mutations. J Neurosci 2000; 20:163-70

78 Matsushita K, Wakamori M, Rhyu IJ, Arii T, Oda S, Mori Y, et al. Bidirectional alterations in cerebellar synaptic transmission of tottering and rolling $\mathrm{Ca}^{2+}$ channel mutant mice. J Neurosci 2002; 22: 4388-98.

79 Caddick SJ, Wang C, Fletcher CF, Jenkins NA, Copeland NG, Hosford DA. Excitatory but not inhibitory synaptic transmission is reduced in lethargic (Cacnb4lh) and tottering (Cacnalatg) mouse thalami. J Neurophysiol 1999; 81: 2066-74.

80 Leenders AG, van den Maagdenberg AM, Lopes da Silva FH, Sheng ZH, Molenaar PC, Ghijsen WE. Neurotransmitter release from tottering mice nerve terminals with reduced expression of mutated P- and Q-type $\mathrm{Ca}^{2+}$-channels. Eur J Neurosci 2002; 15: $13-8$

81 Zhou YD, Turner TJ, Dunlap K. Enhanced G protein-dependent modulation of excitatory synaptic transmission in the cerebellum of the $\mathrm{Ca}^{2+}$ channel-mutant mouse, tottering. J Physiol 2003; 547: 497-507.

82 Pagani R, Song M, McEnery M, Qin N, Tsien RW, Toro L, et al. Differential expression of alpha 1 and beta subunits of voltage dependent $\mathrm{Ca}^{2+}$ channel at the neuromuscular junction of normal and $\mathrm{P} / \mathrm{Q} \mathrm{Ca}^{2+}$ channel knockout mouse. Neuroscience 2004; 123: 75-85.

83 Diriong S, Lory P, Williams ME, Ellis SB, Harpold MM, Taviaux $\mathrm{S}$. Chromosomal localization of the human genes for alpha-1 A, alpha-1B, and alpha-1E voltage-dependent $\mathrm{Ca}^{2+}$ channel subunits. Genomics 1995; 30: 605-9.

84 Zhuchenko O, Bailey J, Bonnen P, Ashizawa T, Stockton DW, Amos C, et al. Autosomal dominant cerebellar ataxia (SCA6) associated with small polyglutamine expansions in the alpha (1A)-voltage-dependent calcium channel. Nat Genet 1997; 15: $62-9$.

85 Ophoff RA, Terwindt GM, Vergouwe MN, van Eijk R, Oefner PJ, Hoffman SMG, et al. Familial hemiplegic migraine and episodic ataxia type- 2 are caused by mutations in the $\mathrm{Ca}(2+)$ channel gene CACNL1A4. Cell 1996; 87: 543-52.

86 Eunson LH, Graves TD, Hanna MG. New calcium channel mutations predict aberrant RNA splicing in episodic ataxia. Neurology 2005; 65: 308-10.

87 Imbrici P, Jaffe SL, Eunson LH, Davies NP, Herd C, Robertson $\mathrm{R}$, et al. Dysfunction of the brain calcium channel CaV2.1 in absence epilepsy and episodic ataxia. Brain 2004; 127: 268292.

88 Kaunisto MA, Harno H, Kallela M, Somer H, Sallinen R, Hamalainen E, et al. Novel splice site CACNA1A mutation causing episodic ataxia type 2 . Neurogenetics 2004; 5: 69-73. 
89 Wessman M, Kaunisto MA, Kallela M, Palotie A. The molecular genetics of migraine. Ann Med 2004; 36: 462-73.

90 Trettel F, Mantuano E, Calabresi V, Veneziano L, Olsen AS, Georgescu A, et al. A fine physical map of the CACNA1A gene region on 19p13.1-p13.2 chromosome. Gene 2000; 241: 4550.

91 Kraus RL, Sinnegger MJ, Glossmann H, Hering S, Striessnig J. Familial hemiplegic migraine mutations change alpha(1 A)Ca (2+) channel kinetics. J Biol Chem 1998; 273: 5586-90.

92 Kraus RL, Sinnegger MJ, Koschak A, Glossmann H, Stenirri S, Carrera $\mathrm{P}$, et al. Three new familial hemiplegic migraine mutants affect $\mathrm{P} / \mathrm{Q}$-type $\mathrm{Ca}(2+)$ channel kinetics. J Biol Chem 2000; 275: 9239-43.

93 van den Maagdenberg AMJM, Pietrobon D, Pizzorusso T, Kaja $\mathrm{S}$, Broos LAM, Cesetti T, et al. A Cacnala knockin migraine mquse model with increased susceptibility to cortical spreading depression. Neuron 2004; 41: 701-10.

94 Ducros A, Denier C, Joutel A, Vahedi K, Michel A, Darcel F, et al. Recurrence of the T666M calcium channel CACNA1 A gene mutation in familial hemiplegic migraine with progressive cerebellar ataxia. Am J Hum Genet 1999; 64: 89-98.

95 Ducros A, Denier C, Joutel A, Cecillon M, Lescoat C, Vahedi K, et al. The clinical spectrum of familial hemiplegic migraine associated with mutations in a neuronal calcium channel. New Engl J Med 2001; 345: 17-24.

96 Manto MU. The wide spectrum of spinocerebellar ataxias (SCAs). Cerebellum 2005; 4: 2-6.

97 Zhuchenko O, Bailey J, Bonnen P, Ashizawa T, Stockton DW, Amos C, et al. Autosomal dominant cerebellar ataxia (SCA6) associated with small polyglutamine expansions in the alpha (1A)-voltage-dependent calcium channel. Nat Genet 1997; 15 : 62-9.

98 Ishikawa K, Tanaka H, Saito M, Ohkoshi N, Fujita T, Yoshizawa $\mathrm{K}$, et al. Japanese families with autosomal dominant pure cerebellar ataxia map to chromosome 19p13.1-p13.2 and are strongly associated with mild CAG expansions in the spinocerebellar ataxia type 6 gene in chromosome 19p13.1. Am J Hum Genet 1997; 61: 336-46.

99 Kordasiewicz HB, Thompson RM, Clark HB, Gomez CM. Ctermini of $\mathrm{P} / \mathrm{Q}$-type $\mathrm{Ca}^{2+}$ channel \{alpha\} $1 \mathrm{~A}$ subunits translocate to nuclei and promote polyglutamine-mediated toxicity. Hum Mol Genet 2006;15: 1587-99.

100 Jones OT. $\mathrm{Ca}^{2+}$ channels and epilepsy. Eur J Pharmacol 2002; 447: 211-25.

101 Sander T, Peters C, Janz D, Bianchi A, Bauer G, Wienker TF, et al. The gene encoding the alpha1 A-voltage-dependent calcium channel (CACN1A4) is not a candidate for causing common subtypes of idiopathic generalized epilepsy. Epilepsy Res 1998; 29: $115-22$

102 Chioza B, Wilkie H, Nashef L, Blower J, McCormick D, Sham P, et al. Association between the alpha-1A calcium channel gene CACNA1A and idiopathic generalized epilepsy. Neurology 2001; 56: $1245-6$.

103 Chioza B, Nashef L, Asherson P, Makoff A. CACNA1A and P/ Q-type calcium channels in epilepsy. Lancet 2002; 359: 258.

104 Sander T, Toliat MR, Heils A, Becker C, Nurnberg P. Failure to replicate an allelic association between an exon 8 polymorphism of the human alpha(1A) calcium channel gene and com- mon syndromes of idiopathic generalized epilepsy. Epilepsy Res 2002; 49: 173-7.

105 Jouvenceau A, Eunson LH, Spauschus A, Ramesh V, Zuberi SM, Kullmann DM, et al. G.Human epilepsy associated with dysfunction of the brain P/Q-type calcium channel. Lancet 2001; 358: 801-7.

106 Strupp M, Kalla R, Dichgans M, Freilinger T, Glasauer S, Brandt T. Treatment of episodic ataxia type 2 with the potassium channel blocker 4-aminopyridine. Neurology 2004; 62: 16235.

107 Saegusa H, Matsuda Y, Tanabe T. Effects of ablation of N- and R-type $\mathrm{Ca}(2+)$ channels on pain transmission. Neurosci Res 2002; 43: 1-7.

108 Ino M, Yoshinaga T, Wakamori M, Miyamoto N, Takahashi E, Sonoda $\mathrm{J}$, et al. Functional disorders of the sympathetic nervous system in mice lacking the alpha 1B subunit (Cav 2.2) of N-type calcium channels. Proc Natl Acad Sci USA 2001; 98: 5323-8.

109 Newton PM, Orr CJ, Wallace MJ, Kim C, Shin HS, Messing RO. Deletion of N-type calcium channels alters ethanol reward and reduces ethanol consumption in mice. J Neurosci 2004; 24 : 9862-9.

110 Takei T, Saegusa H, Zong S, Murakoshi T, Makita K, Tanabe T. Increased sensitivity to halothane but decreased sensitivity to propofol in mice lacking the N-type $\mathrm{Ca}^{2+}$ channel. Neurosci Lett 2003; 350: 41-5.

111 Kamp MA, Krieger A, Henry M, Hescheler J, Weiergraber M, Schneider T. Presynaptic 'Ca2.3-containing' E-type Ca channels share dual roles during neurotransmitter release. Eur J Neurosci 2005; 21: 1617-25.

112 Breustedt J, Vogt KE, Miller RJ, Nicoll RA, Schmitz D. Alpha1Econtaining $\mathrm{Ca}^{2+}$ channels are involved in synaptic plasticity. Proc Natl Acad Sci USA 2003; 100: 12450-5.

113 Saegusa H, Matsuda Y, Tanabe T. Effects of ablation of N- and R-type $\mathrm{Ca}(2+)$ channels on pain transmission. Neurosci Res 2002; 43:1-7.

114 Jing X, Li DQ, Olofsson CS. Salehi A, Surve VV, Caballero J, et al. CaV2.3 calcium channels control second-phase insulin release. J Clin Invest 2005; 115: 146-54.

115 Mittman S, Guo J, Agnew WS. Structure and alternative splicing of the gene encoding alpha $1 \mathrm{G}$, a human brain $\mathrm{T}$ calcium channel alpha1 subunit. Neurosci Lett 1999; 274:143-6.

116 Yunker AM, Sharp AH, Sundarraj S, Ranganathan V, Copeland TD, McEnery MW. Immunological characterization of T-type voltage-dependent calcium channel CaV3.1 (alpha 1G) and CaV3.3 (alpha 1I) isoforms reveal differences in their localization, expression, and neural development. Neuroscience 2003; 117 : $321-35$.

117 Mizuta E, Miake J, Yano S, Furuichi H, Manabe K, Sasaki N, et al. Subtype switching of T-type $\mathrm{Ca}^{2+}$ channels from Cav3.2 to Cav3.1 during differentiation of embryonic stem cells to cardiac cell lineage. Circ J 2005; 69: 1284-9.

118 Anderson MP, Mochizuki T, Xie J, Fischler W, Manger JP, Talley EM, et al. Thalamic Cav3.1 T-type $\mathrm{Ca}^{2+}$ channel plays a crucial role in stabilizing sleep. Proc Natl Acad Sci USA 2005; 102: 1743-8.

119 Lee J, Kim D, Shin HS. Lack of delta waves and sleep disturbances during non-rapid eye movement sleep in mice lacking alpha1G-subunit of T-type calcium channels. Proc Natl Acad 
Sci USA 2004; 101: 18195-9.

120 Mangoni ME, Traboulsie A, Leoni AL, Couette B, Marger L, Le Quang K, et al. Bradycardia and slowing of the atrioventricular conduction in mice lacking CaV3.1/\{alpha\}1G T-type calcium channels. Circ Res 2006; 98: 1422-30.

121 Cribbs LL, Lee JH, Yang J, Satin J, Zhang Y, Daud A, et al. Cloning and characterization of alpha $1 \mathrm{H}$ from human heart, a member of the T-type $\mathrm{Ca}^{2+}$ channel gene family. Circ Res 1998; 83: 103-9.

122 Bourinet E, Alloui A, Monteil A, Barrere C, Couette B, Poirot O, et al. Silencing of the CaV3.2 T-type calcium channel gene in sensory neurons demonstrates its major role in nociception. EMBO J 2005; 24: 315-24.

123 Chen CC, Lamping KG, Nuno DW, Barresi R, Prouty SJ, Lavoie $\mathrm{JL}$, et al. Abnormal coronary function in mice deficient in alpha1H T-type $\mathrm{Ca}^{2+}$ channels. Science 2003; 302: 1416-8.

124 Stamboulian S, Kim D, Shin HS, Ronjat M, De WM, Arnoult C. Biophysical and pharmacological characterization of spermatogenic T-type calcium current in mice lacking the CaV3.1 (alpha1G) calcium channel: CaV3.2 (alpha1H) is the main functional calcium channel in wild-type spermatogenic cells. J Cell Physiol 2004; 200: 116-24.

125 Chen Y, Lu J, Pan H, Zhang Y, Wu H, Xu K, et al. Association between genetic variation of CACNA1H and childhood absence epilepsy. Ann Neurol 2003; 54: 239-43

126 Khosravani H, Altier C, Simms B, Hamming KS, Snutch TP, Mezeyova J, et al. Gating effects of mutations in the Cav3.2 Ttype calcium channel associated with childhood absence epilepsy. J Biol Chem 2004; 279: 9681-84

127 Heron SE, Phillips HA, Mulley JC, Mazarib A, Neufeld MY, Berkovic SF, et al. Genetic variation of CACNA1H in idiopathic generalized epilepsy. Ann Neurol 2004; 55: 595-6.

128 Wolfe JT, Wang H, Howard J, Garrison JC, Barrett PQ. T-type calcium channel regulation by specific G-protein beta-gamma subunits. Nature 2003; 424: 209-13,

129 Mittman S, Guo J, Emerick MC, Agnew WS. Structure and alternative splicing of the gene encoding alpha-1I, a human brain T calcium channel alpha-1 subunit. Neurosci Lett 1999; 269: 121-4,

130 Talley EM, Cribbs LL, Lee JH, Daud A, Perez-Reyes E, Bayliss DA. Differential distribution of three members of a gene family encoding low voltage-activated (T-type) calcium channels. J Neurosci 1999;19: 1895-911.

131 Perez-Reyes E. Molecular physiology of low-voltage-activated t-type calcium channels. Physiol Rev 2003; 83: 117-61.

132 Wan J, Khanna R, Sandusky M, Papazian DM, Jen JC, Baloh RW. CACNA1A mutations causing episodic and progressive ataxia alter channel trafficking and kinetics. Neurology 2005; 64: 2090-7.

133 Hoda JC, Zaghetto F, Koschak A, Striessnig J. Congenital stationary night blindness type 2 mutations S229P, G369D, L1068P, and W1440X alter channel gating or functional expression of $\mathrm{Ca}(\mathrm{V}) 1.4$ L-type $\mathrm{Ca}^{2+}$ channels. J Neurosci 2005; 25: 252-9.

134 Hoda JC, Zaghetto F, Singh A, Koschak A, Striessnig J. Effects of congenital stationary night blindness type 2 mutations R508Q and $\mathrm{L} 1364 \mathrm{H}$ on CaV1.4 L-type $\mathrm{Ca}^{2+}$ channel function and expression. J Neurochem 2006; 96: 1648-58.
135 Jacobi FK, Hamel CP, Arnaud B, Blin N, Broghammer M, Jacobi PC, Apfelstedt-Sylla E, Pusch CM. A novel CACNA1F mutation in a french family with the incomplete type of X-linked congenital stationary night blindness. Am J Ophthalmol 2003; 135: 733-6.

136 Sun W, McPherson JD, Hoang DQ, Wasmuth JJ, Evans GA, Montal M. Mapping of a human brain voltage-gated calcium channel to human chromosome 12p13-pter. Genomics 1992; 14: 1092-1094.

137 Kors EE, Terwindt GM, Vermeulen FL, Fitzsimons RB, Jardine $\mathrm{PE}$, Heywood $\mathrm{P}$, et al. Delayed cerebral edema and fatal coma after minor head trauma: role of the CACNA1A calcium channel subunit gene and relationship with familial hemiplegic migraine. Ann Neurol 2001; 49: 753-60.

138 Battistini S, Stenirri S, Piatti M, Gelfi C, Righetti PG, Rocchi R, et al. A new CACNA1A gene mutation in acetazolamide-responsive familial hemiplegic migraine and ataxia. Neurology 1999; 53: 38-43.

139 Vahedi K, Denier C, Ducros A, Bousson V, Levy C, Chabriat H, et al. CACNA1A gene de novo mutation causing hemiplegic migraine, coma, and cerebellar atrophy. Neurology 2000; 55: 1040-2.

140 Carrera P, Piatti M, Stenirri S, Grimaldi LM, Marchioni E, Curcio $\mathrm{M}$, et al. Genetic heterogeneity in Italian families with familial hemiplegic migraine. Neurology 1999; 53: 26-33.

141 Gardner K. The genetic basis of migraine: how much do we know? Can J Neurol Sci 1999; 26(Suppl 3): S37-43.

142 Denier C, Ducros A, Vahedi K, Joutel A, Thierry P, Ritz A, et al. High prevalence of CACNA1A truncations and broader clinical spectrum in episodic ataxia type 2. Neurology 1999; 52: 1816-21.

143 Scoggan KA, Chandra T, Nelson R, Hahn AF, Bulman DE. Identification of two novel mutations in the CACNA1A gene responsible for episodic ataxia type 2. J Med Genet 2001; 38: 249-53.

144 Matsuyama Z, Murase M, Shimizu H, Aoki Y, Hayashi M, Hozumi I, et al. A novel insertion mutation of acetazolamide-responsive episodic ataxia in a Japanese family. J Neurol Sci 2003; 210: 91-3.

145 Yue Q, Jen JC, Thwe MM, Nelson SF, Baloh RW. De novo mutation in CACNA1A caused acetazolamide-responsive episodic ataxia. Am J Med Genet 1998; 77: 298-301.

146 Friend KL, Crimmins D, Phan TG, Sue CM, Colley A, Fung VS, et al. Detection of a novel missense mutation and second recurrent mutation in the CACNA1A gene in individuals with EA-2 and FHM. Hum Genet 1999; 105: 261-5.

147 Spacey SD, Hildebrand ME, Materek LA, Bird TD, Snutch TP. Functional implications of a novel EA-2 mutation in the P/Qtype calcium channel. Ann Neurol 2004; 56: 213-20.

148 Tonelli A, D'Angelo MG, Salati R, Villa L, Germinasi C, Frattini $\mathrm{T}$, et al. Early onset, non fluctuating spinocerebellar ataxia and a novel missense mutation in CACNA1A gene. J Neurol Sci 2006; 241: 13-7.

149 Jarvis SE, Barr W, Feng ZP, Hamid J, Zamponi GW. Molecular determinants of syntaxin 1 modulation of $\mathrm{N}$-type calcium channels. J Biol Chem 2002; 277: 44399-407.

150 Wiser O, Bennett MK, Atlas D. Functional interaction of syntaxin and SNAP-25 with voltage-sensitive L- and N-type $\mathrm{Ca}^{2+}$ channels. EMBO J 1996; 15: 4100-10. 
151 Magga JM, Jarvis SE, Arnot MI, Zamponi GW, Braun JE. Cysteine string protein regulates $\mathrm{G}$ protein modulation of $\mathrm{N}$-type calcium channels. Neuron 2000; 28: 195-204.

152 Sheng ZH, Yokoyama CT, Catterall WA. Interaction of the synprint site of $\mathrm{N}$-type $\mathrm{Ca}^{2+}$ channels with the $\mathrm{C} 2 \mathrm{~B}$ domain of synaptotagmin I. Proc Natl Acad Sci USA 1997; 94: 5405-10.

153 Maximov A, Sudhof TC, Bezprozvanny I. Association of neuronal calcium channels with modular adaptor proteins. J Biol Chem 1999; 274: 24453-6.

154 Erickson MG, Alseikhan BA, Peterson BZ, Yue DT. Preassociation of calmodulin with voltage-gated $\mathrm{Ca}^{2+}$ channels revealed by FRET in single living cells. Neuron 2001; 31: 973-85.

155 Strock J, Diverse-Pierluissi MA. $\mathrm{Ca}^{2+}$ channels as integrators of $\mathrm{G}$ protein-mediated signaling in neurons. Mol Pharmacol 2004;
66: $1071-6$.

156 Altier C, Dubel SJ, Barrere C, Jarvis SE, Stotz SC, Spaetgens RL, et al. Trafficking of L-type calcium channels mediated by the postsynaptic scaffolding protein AKAP79. J Biol Chem 2002; 277: 33598-603.

157 Lee D, Obukhov AG, Shen Q, Liu Y, Dhawan P, Nowycky MC, et al. Calbindin-D(28k) decreases L-type calcium channel activity and modulates intracellular calcium homeostasis in response to $\mathrm{K}(+)$ depolarization in a rat beta cell line RINr104638. Cell Calcium 2006; 39: 475-85.

158 Hudmon A, Schulman H, Kim J, Maltez JM, Tsien RW, Pitt GS. CaMKII tethers to L-type $\mathrm{Ca}^{2+}$ channels, establishing a local and dedicated integrator of $\mathrm{Ca}^{2+}$ signals for facilitation. J Cell Biol 2005; 171: 537-47. 